\title{
THE CHEMICAL COMPOSITION OF DIARRHEAL AS COMPARED WITH NORMAL STOOLS IN INFANTS *
}

\author{
L. EMMETT HOLT, M.D. \\ ANGELIA M. COURTNEY AND HELEN L. FALES \\ NEW YORK
}

It has been a matter of considerable surprise on going through medical literature to see how little has been written regarding the chemical composition of diarrheal as compared with normal stools. Stools of all varieties have been studied in many ways in great detail since the work of Uffelmann and Wegscheider about forty-five years ago. Numerous reports have been published of metabolism work which contain stool analyses made with reference to the different constituents, fat, nitrogen, ash, etc.; and scattered through these are found reports of isolated instances in which very loose stools have been studied, but, so far as we are aware, no attempt has been made to correlate the observations on diarrheal stools and compare them with those which were normal. The work done on diarrheal stools as such has been chiefly a study of the flora.

It was with the belief that some new light might possibly be thrown on the treatment of such conditions, dietetic and otherwise, that we have made from another point of view a restudy of our metabolism observations, namely, to determine the actual chemical composition of diarrheal stools and compare them with the normal.

Those whose observation on infants' stools is limited to an inspection of napkins can form but an imperfect idea of even the gross condition of the infants' excretions, especially as to the amount of water which they contain. When stools are received in a metabolism basin a very different impression is made.

With the two large factors in the production of loose stools, that is, increased secretion and increased peristalsis, every one is familiar. But many questions arise relating to diarrheal stools. Do very loose stools differ from normal ones only in that they contain more water, or do they actually represent a much greater loss of solids? Are all the solids in the stool affected to the same degree, or are some drained

\footnotetext{
* Submitted for publication Nov. 15, 1914.

* Read at a meeting of the American Pediatric Society, Stockbridge, Mass., May 26, 1914.

* From the Laboratories of the Babies' Hospital and the Rockefeller Institute.
} 
away much more than others? Does the actual loss, or the percentage of intake lost, vary only with the food, or are there other important factors?

These were some of the questions regarding which it was thought information might be gained by such a study as that undertaken. The data have been derived by going through the records of our metabolism studies for the past four years and selecting from them the cases illustrating the different types of stools. Such records were especially valuable for our purpose, for, although the children studied differed considerably with respect to their condition and the food given, the exact intake of the different food elements had been determined, as well as the composition of the excretion. In a few of the early cases the stool analysis did not go further in the ash estimation than to determine the total ash; but in all the recent ones, including the greater number studied, the composition of the ash had been fully worked out.

While the chemical composition of the stools was much influenced by the food, it did not seem to make much difference what the exciting cause of the diarrhea happened to be, as its effect in draining away fluids and solids from the body was much the same in all cases studied.

For the purpose of this study the cases were divided into (A) formed, firm or pasty stools; (B) loose stools and (C) very loose stools. The division into loose and very loose is a somewhat arbitrary one. We classed as "loose" those in which the total quantity of water lost varied between 100 and 200 c.c. daily; as "very loose" those in which the water exceeded 200 c.c. daily.

No account was taken of the number of evacuations during the day, first, because in metabolism observations this is somewhat difficult to determine, and secondly, for the reason that it is really of little importance. What is essential is the total daily excretion.

In the group A, of stools of normal consistency and appearance, there were observations made on 9 patients for 11 periods. In the group $\mathrm{B}$, loose stools, there were observations made on 8 patients for 14 periods. In the group $C$, very loose stools, observations were made on 6 patients for 10 periods. In all, observations were made on 21 patients for 35 periods, for a total of 128 days.

A different period signifies an observation on the same child at another time or on another food. In all but two instances each period was for a longer time than a single day; usually it was three or four days. This was found convenient and sometimes necessary, since in estimating some of the salts of the ash, of which the quantity was very small, the total secretion of two or three days was needed for a satis- 
factory quantitative determination. The amounts of the substances given in the table represents an average for the period. Two or three days were put in the same period only when the food was the same and the stools similar in character. In all cases daily averages of all the observations are given in the charts, and in several cases we have given the range. The extreme variations were considerable, but not greater than one would expect and not enough to affect the general significance of the findings.

The type of child studied is indicated in the clinical summary of cases appended (Table 1 ).

The average age of the twenty-one children was 9 months (the range being from 4 to 13 months) and the average weight $5,500 \mathrm{gm}$. (about $12 \frac{r}{2}$ pounds). In general, they would be classed as hospital nutrition cases. Those in Group A, however, were digesting well and gaining satisfactorily in weight; those in Groups $B$ and $C$ were suffering from acute, or more often subacute diarrhea, usually of a nonfebrile character. There were no dysenteric cases and none of acute infection or intoxication of the intestines of a severe type.

It will be seen from the table that most of the infants were taking formulas derived from whole milk by various dilutions. This was true in twenty of the thirty-five periods studied. The exact percentages of the milk formulas are given in the table. The numerals indicate the fat, sugar and protein, given in order. Thus, in Case 1, Group A, the food was fat, 2.4 per cent.; sugar, 5 per cent.; protein, 1.8 per cent. The sugar added was lactose unless otherwise specified. In sixteen periods some preparation of maltose was given. Usually this was a fluid preparation, a mixture of maltose and dextrin.

The protein milk (Eizeeissmilch), which was the food in five periods, was made from whole milk and had the following average composition: Of seven samples, fat 3.00 ; sugar 2.90; protein 4.00; ash 0.70 . It was prepared in 10-quart quantities by precipitating 4 per cent. milk with rennet; the curd was carefully washed twice with water and then rubbed through a fine wire sieve with the addition of 10 pints of special buttermilk (fat-free lactic acid milk) and water added up to 10 quarts.

The high ash content of protein milk shown by the analyses was to us a surprise, since the impression has prevailed that the salts have been much reduced by the removal of the whey and by the washing of the curd. These results, however, were based on seven complete examinations including thirteen samples, some of these being composite samples. Prepared in the manner described, the range of the salts in protein milk was from 0.54 to 0.74 per cent. 


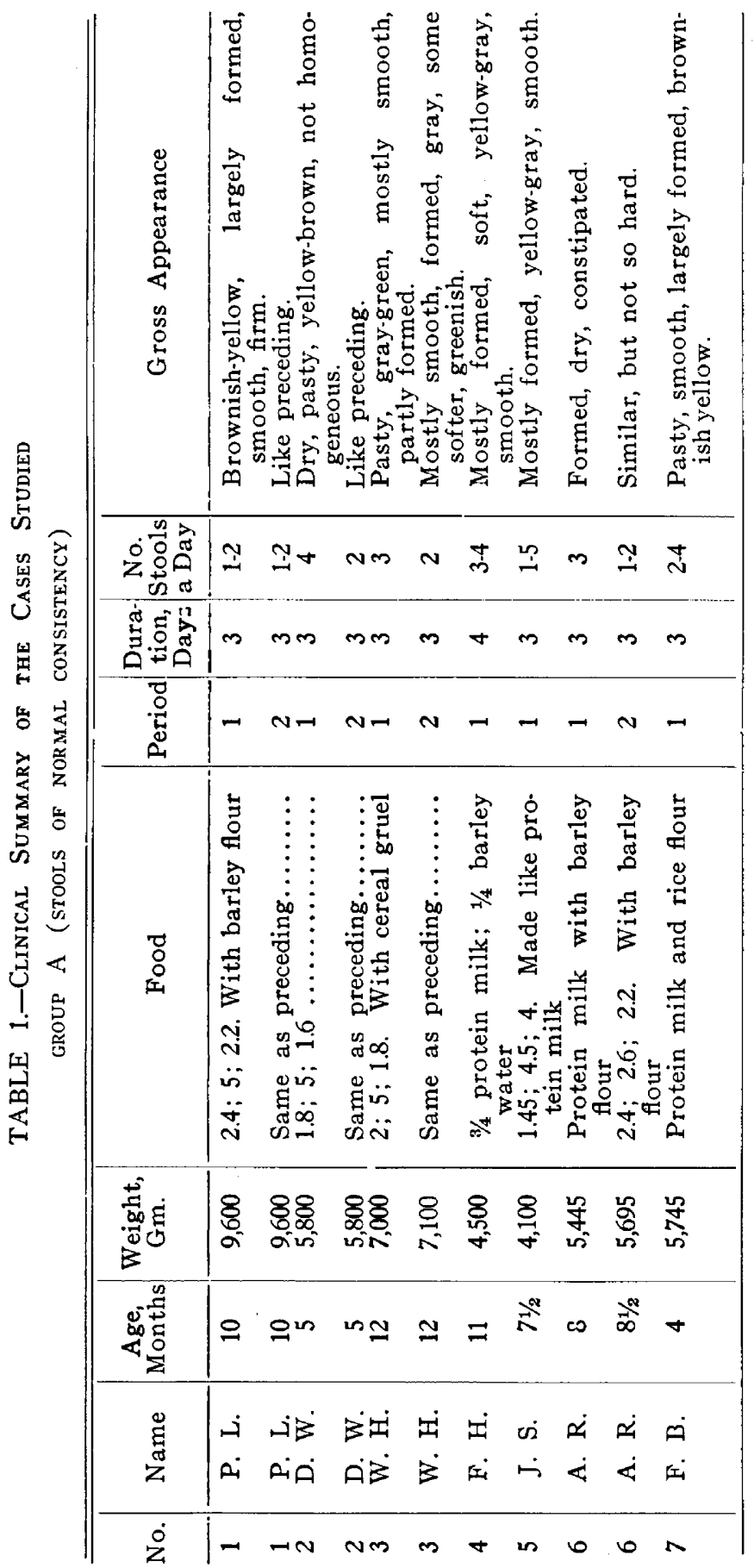

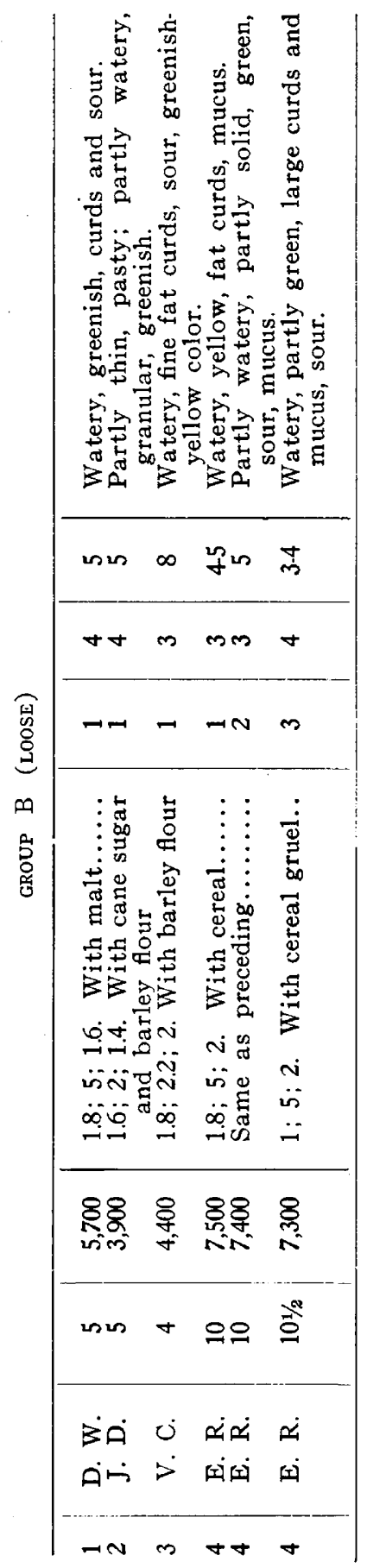




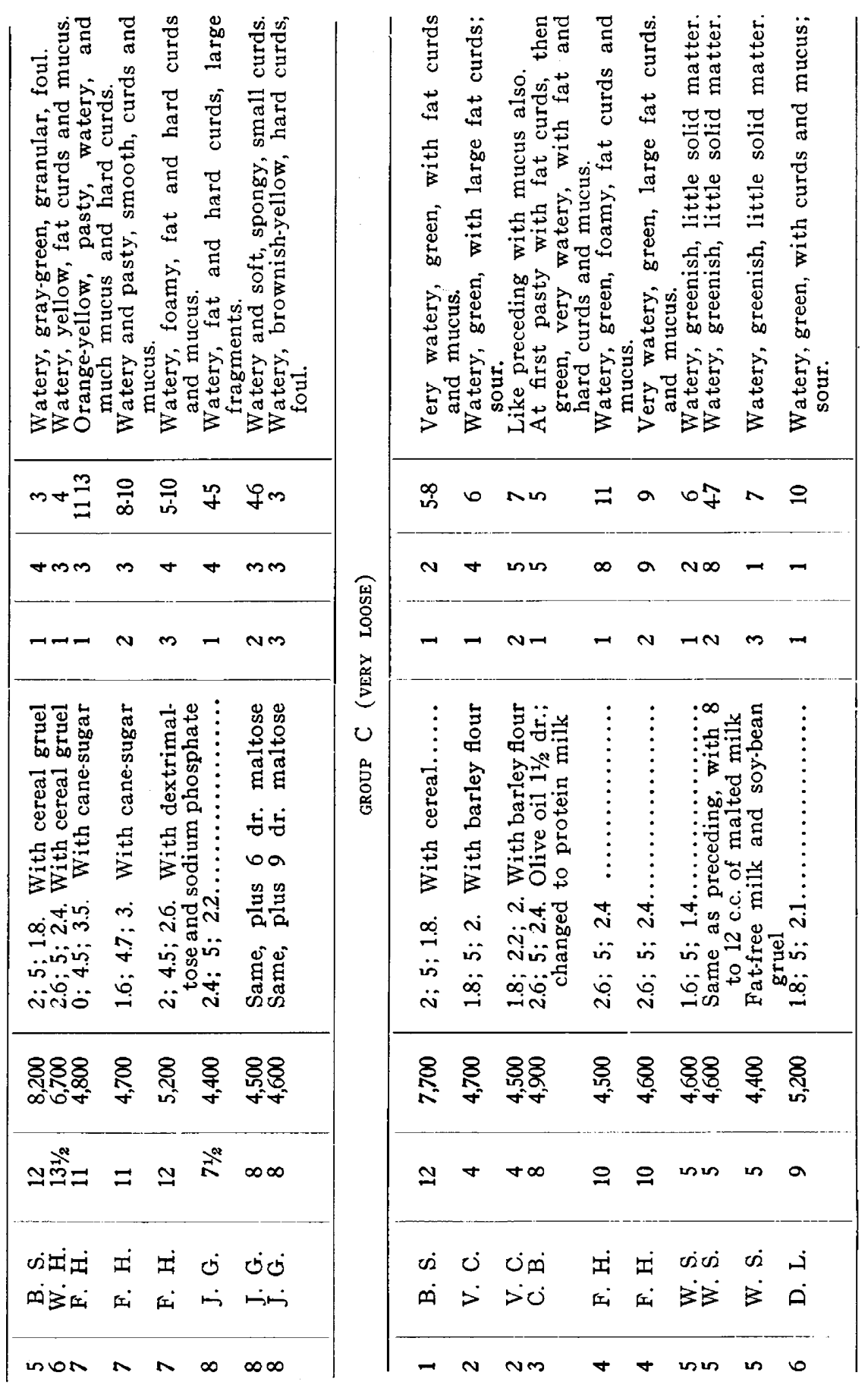


Table 2 gives the percentage of water and dried matter in stools of different types, showing both the averages and the range met with in the series.

TABle 2.-Percentage Composition of Stools Studied

\begin{tabular}{|c|c|c|c|c|c|c|}
\hline & \multicolumn{2}{|c|}{$\begin{array}{c}\text { Stools of } \\
\text { Norma1Consistency }\end{array}$} & \multicolumn{2}{|c|}{ Loose } & \multicolumn{2}{|c|}{ Very Loose } \\
\hline & \multicolumn{2}{|c|}{$\begin{array}{l}\text { Seven Patients } \\
\text { Eleven Periods }\end{array}$} & \multicolumn{2}{|c|}{$\begin{array}{l}\text { Eight Patients } \\
\text { Fourteen Periods }\end{array}$} & \multicolumn{2}{|c|}{$\begin{array}{l}\text { Six Patients } \\
\text { Ten Periods }\end{array}$} \\
\hline & $\begin{array}{c}\text { Average } \\
\%\end{array}$ & $\underset{\%}{\text { Range }}$ & $\begin{array}{c}\text { Average } \\
\%\end{array}$ & $\underset{\%}{\text { Range }}$ & $\underset{\%}{\text { Average }}$ & $\underset{\%}{\operatorname{Range}}$ \\
\hline $\begin{array}{l}\text { Water ........ } \\
\text { Dried matter. }\end{array}$ & $\begin{array}{l}80.3 \\
19.7\end{array}$ & $\begin{array}{l}(73-85) \\
(15-27)\end{array}$ & $\begin{array}{r}91 \\
9\end{array}$ & $\begin{array}{r}(88-92) \\
(8-12)\end{array}$ & $\begin{array}{r}93 \\
7\end{array}$ & $\begin{array}{r}(90-96) \\
(4-10)\end{array}$ \\
\hline
\end{tabular}

\section{METHODS EMPLOYED}

Food and feces were each dried on a steam-bath to a constant weight in equilibrium with room temperature and humidity, and all the determinations were made on this dried material. Each of the urine values was obtained separately from liquid samples. The fat in both the food and the feces was determined by extracting with ether according to a modification of the Soxhlet method and weighing the extract.

Total nitrogen was determined in the dried material and in the urine by the Kjeldahl-Gunning method. We have in our tables regarded all the nitrogen as representing protein; with the knowledge, however, that there is here a small error, as other nitrogen compounds, not protein, are present both in the urine and the stools and possibly also in the food. The amount, however, is so small in the infant as to be negligible for our purposes.

Total ash in dried food and feces and in urine evaporated to dryness was determined in most cases by the Stolte method. According to this method a platinum dish containing the sample is set on pieces of broken pipe-clay inside a porcelain dish. Low heat from a large-sized Teklu burner is applied to the porcelain dish until the material is well charred, after which the heat is gradually increased to the greatest possible point. When most of the black has disappeared the platinum dish is covered by a piece of platinum foil and the heating continued until ashing is completed. No sodium or potassium chlorid is volatilized by this treatment. A few of the earlier samples here reported were ashed over a free flame with the addition of a few drops of acid.

Chlorin was determined in the urine by titration with silver nitrate, according to Volhard. In the dried material in most of the samples the extract, to which nitric acid and ferric alum had been added, was filtered after several hours' standing and titrated with silver nitrate. In the earlier cases the sample was charred, sometimes after being mixed with sodium carbonate, extracted with water, filtered and the filtrate was titrated with silver nitrate.

Phosphates in the urine were determined by titration with uranium acetate or nitrate, potassium ferrocyanid being used as indicator. In the dried material the Neumann method has been used in most cases, that is phosphoric acid precipitated in the ashed material as phosphomolybdate, dissolved by ammonia and reprecipitated by magnesia mixture as magnesium ammonium phosphate and weighed after ignition as pyrophosphate. In some of the earlier samples the Vozárik method was followed. According to this the material is well mixed with magnesium oxid and ashed, the residue dissolved in hydrochloric acid, sodium acetate and acetic acid added to the neutralized solution and phos- 


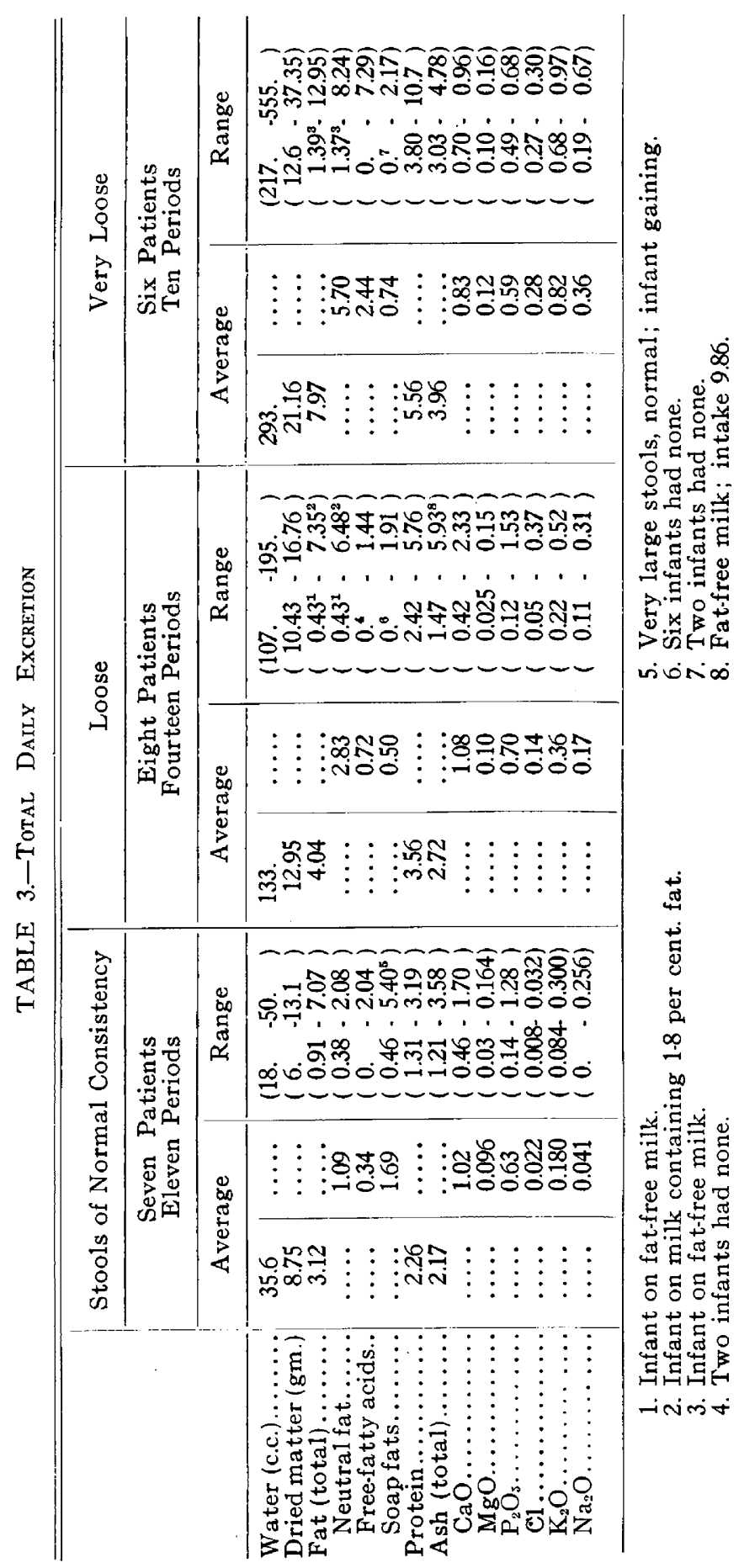


phoric acid determined by titration with uranium nitrate. Calcium and magnesium, sodium and potassium were determined in dried material of food and feces and urine by the ordinary methods, calcium being precipitated as oxalate and weighed as oxid, magnesium weighed as pyrophosphate, sodium and potassium separated as chlorids and potassium determined by precipitation with platinic chlorid.

Tables 3 and 4 give the actual and the percentage composition of the stools of different types. Very loose stools contain not only a very large amount of water, but the quantity of dried matter lost daily is much greater than that lost in stools of normal consistency. It varies somewhat with the food, but principally with the amount of water.

Fat.-The fats particularly vary in most cases directly with the amount of water. A child who is losing twice as much water is usually losing twice as much fat in his stool. A very high fat loss, however, is also sometimes seen in dry, formed, soapy stools. The average loss of fat in loose stools was two and a half times that seen in normal stools. The percentage of fat varies widely; the average was 37.7 per cent. of the dried matter in the very loose stools, the highest found being 62.2 per cent. of the dried matter of the stool. The highest found in stools of normal consistency was 54 per cent.

The form of fat differs much in the different types of stools. In the normal pasty stools the soap fats are present in largest amount. The soaps form on the average 54.3 per cent., while the neutral fat forms but 39.4 per cent. of the total fat of the stool. In very loose stools these ratios are reversed. The greatest proportion of the fat (64.2 per cent.) is neutral fat, while soaps form but a small proportion (8.3 per cent.) of the total. In eight observations on infants with loose or very loose stools, no soaps at all were formed. This is what might be expected to occur when the intestinal contents are hurried through the bowel too rapidly for saponification to take place. Free fatty acids represent those not combined with bases to form soaps; their amounts also were higher in the loose than in the normal stools and much higher in the very loose stools.

Protein.-The daily amount of protein lost in the stools calculated from the nitrogen is about two and a half times greater in very loose than in normal stools; it being in about the same ratio in the two as the fat. The percentage of the dried matter of the stool which is protein is nuarly the same in the stools of the different classes.

Ash.-It is well known that the ash represents a considerable part of the dried matter of the stools, but that in normal, pasty stools it is equal to two-thirds the fat is not generally appreciated. In loose stools about the same relation of fat and ash is preserved, while in watery stools the proportion of fat is relatively higher. The amount of ash in 


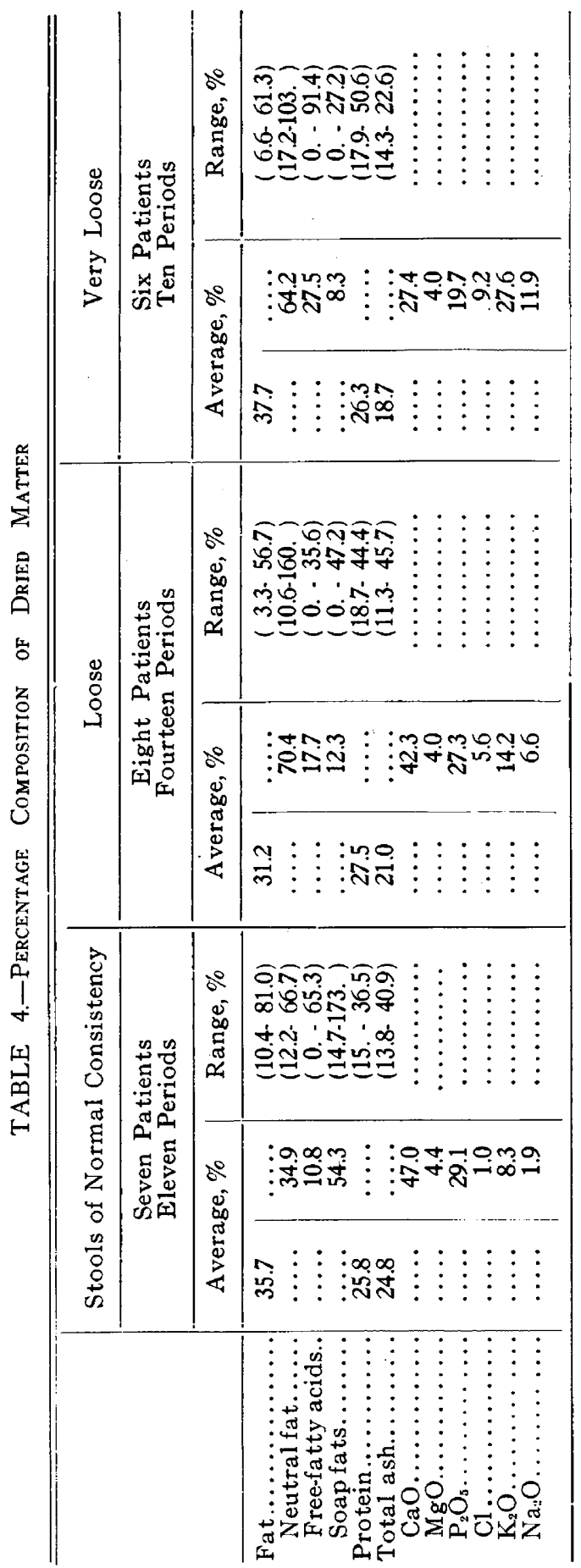


some individual cases is interesting. In one normal stool it formed over 40 per cent. of the dried matter of the stool and in one loose stool, over 45 per cent.

When we study the distribution of the salts which make up the total ash it is seen that, while the percentage of the total varies, the actual amount of calcium is nearly the same in normal and loose stools, but is lowest in very loose stools; the quantity of all the other salts, notably sodium and potassium, however, is very greatly increased.

Residue of Dried Matter not Accounted For.-In going over our figures it was evident that there was a considerable percentage of the dried matter not accounted for as fat, protein and ash. This is indicated in Table 5 .

TABlE 5.-Percentage of Dried Matter of Stools Not Accounted for as Fat, Protein and Ash

\begin{tabular}{|c|c|c|c|c|}
\hline Stools & $\begin{array}{c}\text { Dried } \\
\text { Weight, } \\
\text { Gm. }\end{array}$ & $\begin{array}{l}\text { Sum of Fat, } \\
\text { Ash and Pro- } \\
\text { tein, Gm. }\end{array}$ & $\begin{array}{l}\text { Balance not } \\
\text { Accounted } \\
\text { for, Gm. }\end{array}$ & $\begin{array}{l}\text { Per cent. of } \\
\text { Dried } \\
\text { Weight }\end{array}$ \\
\hline 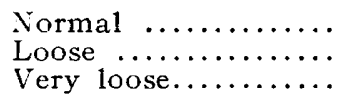 & $\begin{array}{r}8.75 \\
12.95 \\
21.16\end{array}$ & $\begin{array}{r}7.55 \\
10.32 \\
17.49\end{array}$ & $\begin{array}{l}1.20 \\
2.63 \\
3.67\end{array}$ & $\begin{array}{l}13.7 \\
20.3 \\
17.3\end{array}$ \\
\hline
\end{tabular}

This unexplained residue varies greatly; in some stools it was only 3 or 4 per cent. of the total; in others it amounted to 25 per cent. of the dried matter of the stool examined. In a review of the literature of the past dozen years we have not found any attempt at explanation of what this unaccounted-for residue is. It is sometimes referred to as "other substances," but usually is entirely ignored.

Exactly what it is has not yet been determined by the direct method. The probabilities are that it is made up chiefly of the cellulose derived from the bodies of bacteria. Evidence of this is found in the carbon content of the dried organic matter after the extraction of the fat. As determined by combustion, the dried matter minus fat was found to contain about 43 per cent. carbon. As protein contains 52 to 54 per cent. of carbon, and carbohydrate but 44 per cent., this substance is probably chiefly carbohydrate. This carbohydrate is certainly not derived from the food. The sugar ingested is either absorbed or undergoes fermentation in the alimentary tract. It is true that many of our children were taking starch, some of them in considerable amounts. But in only exceptional stools could the presence of starch be demonstrated by microchemical tests, and then only in minimal quantities. It was in no case sufficient to account for the carbohydrate content of the stool. Furthermore, just as great carbohydrate content 
existed in the stools of many children who were receiving no starch at all. The evidence therefore all points to cellulose derived from the bodies of bacteria as the chief factor in this dried matter unaccounted for.

The proportion of the stool made up of bacteria is great, making, according to various investigators, from 10 to 40 per cent. of the dried matter; in some constipated stools in infants it is estimated to have made up two-thirds of the stool.

TABLE 6.-Ratio of Intake to Excretion and Pircentage of Intake Lost in Stools

\begin{tabular}{|c|c|c|c|c|c|c|}
\hline \multirow[b]{3}{*}{ 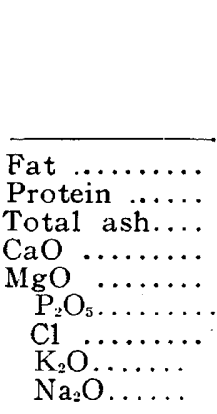 } & \multicolumn{2}{|c|}{ Normal } & \multicolumn{2}{|c|}{ Loose* } & \multicolumn{2}{|c|}{ Very Looset } \\
\hline & $\begin{array}{l}\text { Seven } \\
\text { Eleve }\end{array}$ & $\begin{array}{l}\text { Patients } \\
\text { Periods }\end{array}$ & $\begin{array}{l}\text { Eight } \\
\text { Fourte }\end{array}$ & $\begin{array}{l}\text { Patients } \\
\text { Periods }\end{array}$ & $\begin{array}{l}\text { Six } \\
\text { Ten }\end{array}$ & $\begin{array}{l}\text { atients } \\
\text { eriods }\end{array}$ \\
\hline & $\begin{array}{r}12.4 \\
7.7 \\
40.0 \\
67.2 \\
56.7 \\
36.9 \\
3.7 \\
15.4 \\
12.3\end{array}$ & $\begin{array}{c}\cdots \\
\cdots \\
\text { (in urine) } \\
\text { Trace } \\
\text { Trace } \\
36.7 \\
79.0 \\
54.9 \\
67.5\end{array}$ & $\begin{array}{l}23.1 \\
14.9 \\
46.6 \\
70.2+ \\
66.0 \\
41.4 \\
17.7 \\
37.98 \\
37.0\end{array}$ & $\begin{array}{c}\ldots \ldots \\
\text { (in urine) } \\
\text { Trace } \\
\text { Trace } \\
36.0 \\
70.2 \\
37.9 \\
28.2\end{array}$ & $\begin{array}{r}40.5 \\
25.2 \\
84.3 \\
79.0 \\
100.0 \\
48.3 \\
52.9 \\
83.7 \\
103.0\end{array}$ & $\begin{array}{c}\cdots \\
\cdots \\
\text { (in urine) } \\
\text { Trace } \\
\text { Trace } \\
41.7 \\
17.0 \\
26.6 \\
5.7\end{array}$ \\
\hline
\end{tabular}

* In six periods the sodium and potassium distribution was not determined.

$\dagger$ Complete distribution of ash was determined in only four periods.

$¥$ Fourteen periods.

Eight periods.

Ratio of Intake to Excretion.--In the normal stool the loss of fat was but 12.4 per cent. of the intake, while in the very loose stools it reached 40.5 per cent. It is known that fat may be demonstrated in. the stool when none is given in the food, it being derived from the intestinal secretions; but the amount is very small and from a nutritive point of view it is a negligible quantity. The loss of protein in the normal stool estimated from the nitrogen content represents but 7.7 per cent. of the intake. This shows how completely the protein of cow's milk is digested and absorbed by the average child. In the loose stools, calculating all the nitrogen as representing protein, the loss is 14.9 per cent. of the intake, and in very loose stools it is 25.2 per cent. This is not strictly true. In loose stools, and especially in watery stools, a considerable amount of protein present is not derived from the food, but is drained away from the body in the intestinal secretions. How much this is we are as yet unable to estimate, but it must be quite large. It is probable that although the infant with diarrhea loses over 40 per cent. of the fat which is given, he does not lose 25 per cent. of the protein given. This is incidental, but very important confirmatory evidence of 
the value of protein feeding in diarrhea which has received so much support from clinical observations. When we study the distribution of the salts which make up the ash it is evident that they are not derived entirely from the food ingested, but that they represent a considerable draining away of salts from the body itself. In normal stools nearly four-fifths (76.1 per cent.) of the ash is calcium oxid and phosphoric acid, probably existing in the stool as calcium phosphate, while the proportion of chlorin and potassium and sodium oxids together form but 11.2 per cent. of the total. In the dry, formed stools the ash is often high, due to the bases combined with the fats as soaps.

In very loose stools we found calcium oxid and phosphoric acid to form but 47.1 per cent. of the total, but there was a great increase in the proportion of sodium, of potassium and of chlorin; together they make up 48.7 per cent. of the total ash, the chlorin being nine times, the potassium oxid three and a half times, and the sodium oxid six times the proportion in normal stools. This cannot be without significance.

Normally, 40 per cent. of the ash intake is lost in the stools; this is chiefly calcium phosphate, of which cow's milk has so great an excess. In very loose diarrheal stools there is lost 84.3 per cent. of the intake. The proportion of calcium phosphate shows but a moderate increase over that in normal stools, 79 as compared with 67.2 per cent. of the intake. The great increase in the total is made up of the other salts. The magnesium loss is 100 per cent., indicating that it very slowly enters into combinations in which it can be absorbed. The loss of calcium and magnesium occurs almost exclusively in the stools, only traces being found in the urine. Of the remaining elements, the loss in the urine must be considered in estimating the balances. Chlorin, potassium and sodium are normally present in the stools in relatively small amounts, but in the urine in large amounts. In diarrheal stools we find an enormous increase in the quantity present in the stools and a corresponding reduction in the amount eliminated by the urine. But the increase in the stools is so great as to create a negative balance of 10.3 per cent. in potassium and 8.7 per cent. in sodium. This indicates the loss from the body itself.

The ratio of the loss of salts to the intake is one of the most striking characteristics of loose, diarrheal stools and furnishes an important stiggestion as to treatment. In attempting to supply this loss by hypodermoclysis it should be remembered that not only are water and sodium needed, but potassium and magnesium as well. With these facts in mind a better solution for use in hypodermoclysis can certainly be devised than a normal saline or than Ringer's solution.

This subject is still under investigation at the Hospital Laboratories and the foregoing is to be regarded in the nature of a preliminary report. 